\title{
WPROWADZENIE
}

Klio. Czasopismo poświęcone dziejom Polski i powszechnym

PL ISSN 1643-8191, t. 46 (3)/2018, s. 3-7

(c) (1) $\Theta$

Katarzyna PęKacka-Falkowska*

\section{Medycyna i historia naturalna we wczesnej nowożytności. Uwagi ustępne}

Kedy filozofia natury była bezsilna wobec zgłębianego przez nią świata,
chętnie sięgała do poesis. Kiedy zaczęła się zmieniać i iść ręka w rękę z eksperymentalizmem, zmianie uległy także jej forma i język, w tym wykorzystywane gatunki epistemiczne oraz stosowane środki wyrazu. W 1648 roku Samuel Hartlib stwierdził explicite: „przez naukę rozumiemy określony korpus tak uporządkowanych pojęć, by umożliwiły one umysłowi człeka dostrzeżenie zasad wszystkich rzeczy". Zaledwie czterdzieści lat później John Locke uznał natomiast, że ani filozofia natury, ani historia naturalna nigdy nie staną się nauką.

Od czasów antycznych nauka o naturze, w tym medycyna, była zależna od filozofii. Już Galen wyjaśniał, quod optimus medicus sit quoque philosophus. Spekulatywność odgrywała wówczas ważniejszą rolę niż empiria w myśl założenia, że umiejętność praktyczna nigdy nie jest wiedzą. Wyraźna zmiana nastąpiła dopiero w XVII stuleciu, kiedy zaczęto podkreślać znacze-

* Uniwersytet Medyczny im. Karola Marcinkowskiego w Poznaniu, Katedra i Zakład Historii i Filozofii Nauk Medycznych, ul. Przybyszewskiego 37a, 60-356 Poznań; pekackafalkowska@ump.edu.pl; ORCID: 0000-0003-2068-7957. 
nie obserwacji, doświadczenia, klasyfikacji, eksperymentowania, tworzenia nowych systemów opartych na logicznym porządku faktów empirycznych i eksperymentów a nie przypuszczeniach.

Nowa filozofia miała stać się użyteczna, przeprowadzane eksperymenty miały przynosić aplikowalne wyniki oraz takie, które rzuciłyby nowe światło na naturę in genere. Nieustanne przenikanie się rzemiosła i nauki, techne i filozofii powodowały, że do filozofii natury w XVII wieku zaczęto wprowadzać odkrycia m.in. z pola jatrochemii oraz jatromechaniki. Gdzie $\mathrm{w}$ rodzącym się przyrodoznawstwie nowego typu znalazło się miejsce dla historii naturalnej, niebędącej przecież ani rzemiosłem, ani profesją? W jaki sposób postępował mariaż studiów nad naturą z naukami tajemnymi oraz teologią? Jaką rolę odgrywała medicina, quod est ars et scientia, bazująca na indywidualnym doświadczeniu oraz pojedynczej obserwacji? Ponieważ dla lekarzy, botaników i innych curieusi częstokroć nie było miejsca w wielkich towarzystwach naukowych, zakładali oni pomniejsze organizacje, w których kultywowali niezależnie studia nad naturą, oraz powoływali do życia własne uczone żurnale.

Medycyna i historia naturalna w epoce przedklinicznej stanowią współcześnie ważny przedmiot badań z zakresu historii nauki, edukacji, kultury, sztuki, muzealnictwa, filozofii itd. W krajach Zachodu działają liczne wyspecjalizowane centra badawcze łączące pod egidą jednej instytucji przedstawicieli różnych dziedzin i dyscyplin naukowych. Badania nad historią medycyny i przyrodoznawstwa stają się w ten sposób przedsięwzięciem $\mathrm{z}$ gruntu interdyscyplinarnym i uprawianym zbiorowo. W ramach wielkich klasterów badawczych, stanowiących platformy współpracy międzydziedzinowej oraz międzyepokowej, realizuje się liczne projekty naukowe, w tym edytorskie, których efektów nie sposób przecenićp ${ }^{\text {. }}$

W przypadku polskich badań nad historią medycyny wczesnonowożytnej i wczesnonowożytnej historii naturalnej brak rozwiązań analogicznych do tych znanych z Niemiec, Francji, Austrii, Stanów Zjednoczonych itd. Polscy badacze pracują $\mathrm{w}$ rozproszeniu, nierzadko w pojedynkę, nie-

${ }^{1}$ Zob. np. projekty realizowane w Max Planck Institut für Wissenschaftsgeschichte w Berlinie (https://www.mpiwg-berlin.mpg.de) czy Centre Alexandre Koyré w Paryżu (http://koyre.ehess.fr). 
wiele wiedząc o projektach analogicznych do ich własnych, ale prowadzonych przez przedstawicieli innych dyscyplin naukowych niż im właściwa. Katedra Historii i Filozofii Nauk Medycznych Uniwersytetu Medycznego w Poznaniu razem z Fundacją na Rzecz Myślenia im. Barbary Skargi podczas konferencji zorganizowanej $\mathrm{w}$ Poznaniu w dniach 7-8 grudnia 2017 roku podjęła próbę szerszego przyjrzenia się aktualnemu stanowi polskich badań nad historią medycyny i przyrodoznawstwa w epoce preindustrialnej. Wybrane i uzupełnione materiały z tej konferencji, których autorzy reprezentują różne tradycje i ośrodki akademickie, są publikowane $\mathrm{w}$ prezentowanym tomie.

Dział Artykutów otwiera tekst politologa Michała Pospiszyla. Jest to wielopoziomowe studium z zakresu historii idei, w którym autor łączy koncepcje medyczne i polityczne uwidaczniające się w myśli późnośredniowiecznych włoskich teoretyków państwa. Dzięki analizie prac takich myślicieli jak np. Mikołaj z Kuzy, Pospiszyl ukazuje, w jaki sposób idea ciała politycznego była kształtowana przez metafory przynależne do teorii humoralnej biorącej początek u Hipokratesa, a następnie rozwijanej przez Galena. Metafory te, co istotne, zasilały dyskurs polityczny także w późniejszych stuleciach. Również artykuł filozofa Marka Woszczka to wielowymiarowe studium z zakresu history of ideas. Autor na podstawie drobiazgowej analizy opublikowanych prac Paracelsusa oraz wybranych myślicieli przełomu XVI i XVII wieku wskazuje, w jaki sposób paracelsjanizm stał się we wczesnej nowożytności teorią rewolucyjną nie tyle w obrębie ars medica et pharmaceutica, co w myśleniu o społeczeństwie i świecie.

W tekście historyka Andrei Marianiego poddano wielostronnej analizie inwentarze późnoosiemnastowiecznych aptek jezuickich, które znajdują się w zasobach archiwów i bibliotek polskich, wschodnioeuropejskich oraz rosyjskich. Dzięki temu w erudycyjny sposób udało się przedstawić recepcję nowych prądów intelektualnych w kręgu aptekarstwa jezuickiego, społeczną i naukową rolę aptek jezuickich w dawnej Rzeczypospolitej oraz zakres standardowego asortymentu aptecznego - zarówno simplicitów, jak i compositów - w jezuickich klasztorach położonych na semiperyferiach Europy.

$\mathrm{Na}$ inne zagadnienie, mianowicie obecność w kolekcjach magnackich eksponatów ze świata przyrody, uwagę zwróciła historyk sztuki Katarzyna Brzezina-Scheuerer. Autorka omówiła zainteresowania księcia Hieronima 
Floriana Radziwiłła naturą i medycyną, sytuując je w szerszym horyzoncie kultury ciekawości właściwej epoce baroku oraz protooświecenia. W ten sposób pokazała, jak ważne miejsce w staropolskim horyzoncie poznawczym zajmowała historia naturalis i jakie motywacje mogły kierować kolekcjonerami-amatorami w trakcie kompletowania ich zbiorów. Tematyka ta jest istotna o tyle, o ile wciąż - w odróżnieniu od chociażby Śląska - brakuje szerszych studiów poświęconych gabinetom osobliwości i kolekcjom naturaliów w Rzeczypospolitej Obojga Narodów.

Także tekst Darii Nowgorodowej, geologa i kustosza w Muzeum Mineralogicznym im. A. J. Fersmana Rosyjskiej Akademii Nauk, wpisuje się w zakres studiów nad wczesnonowożytnym kolekcjonerstwem. Tym razem jednak przedmiotem analizy staje się specjalistyczna gdańska kolekcja doktora medycyny i filozofii Christopha Gottwalda: Musaeum Gottwaldianum. Część tej kolekcji po śmierci jej drugiego właściciela, syna medyka, Johanna Christopha, została sprzedana carowi Piotrowi I i wywieziona do Sankt Petersburga, stając się jednym z trzech podstawowych zasobów nowo zakładanej Kunstkamery. Opierając się na ustaleniach zaprezentowanych wcześniej w rozprawie doktorskiej, autorka szeroko omówiła dzieje $\mathrm{Mu}$ saeum Gottwaldianum w Rosji w XVIII-XX wieku oraz poddała analizie wchodzące w skład tej kolekcji pojedyncze eksponaty zachowane do dzisiaj w Muzeum Mineralogicznym im. A. J. Fersmana.

Gdańskiej rodzinie Gottwaldów poświęcono także dwa kolejne artykuły. W tekście historyka Piotra Paluchowskiego i lekarza Adama Szarszewskiego przedstawiono najważniejsze zagadnienia poruszane w niemieckojęzycznym dziełku medycznym Johanna Christopha Gottwalda Memoriale Loimicum oraz dalsze losy wydawnicze tej pracy w Wielkiej Brytanii. Dokumentująca przebieg epidemii dżumy w Gdańsku w 1709 roku niemieckojęzyczna rozprawa - mająca charakter jednocześnie egodokumentu i traktatu naukowego - jest obecnie opracowywana przez gdańskich badaczy i przygotowywana po niemal 310 latach do druku w przekładzie na język polski.

Ostatni artykuł, zamieszczony w dziale Materiaty, został natomiast poświęcony instrumentarium chirurgiczno-anatomicznemu i narzędziom malarskim używanym przez Gottwalda seniora w jego badaniach przyrodoznawczych. Obiekty te zobrazowano na miedziorytach z Musaeo Anatomico opracowanym w 1713 roku (na podstawie spuścizny medyka) przez Jo- 
hanna Philippa Breyne'a. Historyk Katarzyna Pękacka-Falkowska nie tylko omówiła zakres warsztatu badawczego jednego z wybijających się medyków XVII wieku związanych z Prusami Królewskimi i Holandią, ale postawiła także hipotezę, że miedzioryty te w zamierzeniu Gottwalda miały stanowić materiał ilustracyjny do opracowywanego przez niego atlasu anatomicznego. Gdyby ów projekt został przez Gottwalda zrealizowany, medyk stałby się pierwszym w historii Rzeczypospolitej Obojga Narodów autorem pełnowymiarowego atlasu anatomicznego wyprzedzając o niemal ćwierć wieku Johanna Adama Kulma i jego Anatomische Tabellen.

Zamieszczone w niniejszym tomie „KLIO” teksty prezentują tylko wybrane problemy oraz tradycje badawcze i interpretacyjne w obrębie współczesnej polskiej historiografii medycyny i przyrodoznawstwa. Katalog zagadnień związanych z tym obszarem badawczym jest bowiem zbyt szeroki, aby udało się go podjąć w trakcie jednej interdyscyplinarnej konferencji. Należy jednak żywić nadzieję, że przedstawione artykuły przyczynią się do ożywienia w Polsce badań nad medycyną i historia naturalis w epoce przedindustrialnej nie tylko wśród przedstawicieli nauk historycznych, lecz także literaturoznawstwa, filozofii, nauk o sztuce, nauk o kulturze i religii oraz innych dyscyplin, nie tylko humanistycznych. 
